\title{
Two-dimensional polyacrylamide gel electrophoresis of proteins synthesized and released by conceptuses and endometria from pony mares
}

\author{
K. J. McDowell*, D. C. Sharp $\dagger$, A. T. Fazleabas $\$$ and R. M. Robertsł $\ddagger$ \\ *Department of Veterinary Science, University of Kentucky, Lexington, Kentucky 40546-0099, \\ USA; and $†$ Department of Animal Science, and $\ddagger$ Department of Biochemistry and Molecular \\ Biology, University of Florida, Gainesville, Florida 32611, USA
}

\begin{abstract}
Summary. Conceptuses were obtained from pony mares on each day of pregnancy between Days 12 and 28, and on Days 39, 45, 65 and 100. Endometrium was obtained from mares at Days 12, 14, 16, 18, 39, 45, 65 and 100 of pregnancy, and from non-pregnant mares during anoestrus, during transition into the breeding season, at oestrus, or during dioestrus. Tissues were incubated in vitro for $24 \mathrm{~h}$ with L- $\left[{ }^{3} \mathrm{H}\right] l$ leucine. Proteins synthesized and released into the culture medium were analysed by twodimensional polyacrylamide gel electrophoresis (2-D PAGE) and fluorography.

Conceptuses obtained before Day 14 after ovulation released a characteristic pattern of labelled proteins. These included two groups of apparent isoelectric variants of relative molecular weights $\left(M_{\mathrm{r}}\right) 30000-40000$ (pI values 4.5-5.5 and 6-7), one group of $M_{\mathrm{r}} \sim 22000$ (pI 6.5-7), and large protein(s) that did not enter the $10 \%$ polyacrylamide gel. After Day 14 the array of labelled proteins had changed and resembled that produced by isolated yolk sac at the later stages of pregnancy studied. Included amongst these were several acidic polypeptides with $M_{\mathrm{r}} 20000$ (pI 5-6).

The endometrial samples released an array of non-dialysable polypeptides into the culture medium. Fluorograms could be assigned to one of three general groups, with endometrium from mares within each group producing similar patterns of labelled proteins. The first group consisted of anoestrous, transitional and ovariectomized mares, and mares at oestrus or Day 1 or Day 18 after ovulation. The second group was comprised of mares at Days 12-16 of dioestrus or Days 12-18 of pregnancy. Mares from Day 39 through 100 of pregnancy made up the third group.
\end{abstract}

Keywords: embryo; horse; proteins; endometrium; electrophoresis

\section{Introduction}

Complex interactions between the conceptus and the maternal unit exist throughout pregnancy. Exchange of biochemical information is evident during the time the conceptus moves through the oviduct (Betteridge \& Mitchell, 1974; Biggers \& Borland, 1976; Betteridge et al., 1979), through the period of maternal recognition of pregnancy (Short, 1969; Beier \& Mootz, 1979) until parturition (Liggins et al., 1973; Bazer \& First, 1983), with carry-over effects influencing the dam post partum (Thatcher et al., 1979).

The horse conceptus is mobile in the uterine lumen from the time it can be detected with ultrasonography (Day 9 or 10) until Days 16-17 (Ginther, 1983). The mobility appears to promote 
signalling events between the conceptus and the endometrium which are essential for luteal maintenance (McDowell et al., 1985, 1988).

Proteins produced by the conceptus and endometrium may serve as molecules of communication by acting as enzymes, hormones or receptors. Changes occur in the proteins and steroids that appear in the uterine lumen of cyclic and early pregnant mares (Zavy et al., 1982a, b, 1984): there were qualitative and quantitative changes in the protein content of the uterine secretions throughout the oestrous cycle, but no proteins were found in the flushings of pregnant mares that were not present in the flushings of non-pregnant mares. Proteins produced by the conceptus could not be detected readily by the methods used (Coomassie blue staining of two-dimensional polyacrylamide gels; Zavy et al., 1982b). Therefore, the purpose of this study was to characterize the proteins synthesized and released in vitro by the pony conceptus, isolated conceptus membranes, and endometrium.

\section{Materials and Methods}

Materials. Tissue culture media and reagents were from Gibco Laboratories (Grand Island, NY, USA) and L- $\left[4,5-{ }^{3} \mathrm{H}\right]$ leucine (sp. act. $340 \mathrm{Ci} / \mathrm{mmol}$ ) was from Amersham Corp. (Arlington Heights, IL, USA). Acrylamide, $\mathrm{N}, \mathrm{N}, \mathrm{N}^{\prime}, \mathrm{N}^{\prime}$-tetra-methylenediamine and XRP-1 X-ray film were products of Eastman-Kodak (Rochester, NY, USA); Coomassie blue R-250, and N,N'-diallyltartardiamide were from Bio-Rad Laboratories (Richmond, CA, USA); SDS and Nonidet P-40 were from BDH Chemicals Ltd (Poole, Dorset, UK); ampholines were from LKB (Uppsala, Sweden); dithiothreitol, protein standards, $\beta$-mercaptoethanol, agarose and tris[hydroxymethyl]aminomethane (Tris) were from Sigma; urea was from Pierce Chemical (Rockford, IL, USA). Acepromazine maleate and Fluothane were obtained from Fort Dodge Laboratories, Inc. (Fort Dodge, IA, USA) and thiamylal sodium was from Boehringer (Ingelheim, West Germany).

Animals. Pony mares were teased daily with a pony stallion to monitor oestrous behaviour, and palpated per rectum every third day to monitor ovarian status until a follicle $>30 \mathrm{~mm}$ in diameter was detected. Mares were then teased and palpated daily and inseminated every other day by natural service or artificially until ovulation was detected. The day of ovulation was designated as Day 0.

Conceptuses were removed non-surgically by flushing the uterus with one litre of sterile $0.9 \% \mathrm{NaCl}(\mathrm{w} / \mathrm{v})$ via a Foley catheter inserted through the cervix on each of Days 12-18, 22 and 28 after ovulation. Conceptuses were obtained at hysterectomy on Days 39, 45, 65 and 100 after ovulation. A minimum of 2 conceptuses was obtained on each day, except on Days 39 and 45, when only one conceptus was obtained on each day.

Endometrium was obtained by transcervical biopsy from non-pregnant mares during deep anoestrus, transition from anoestrus into the breeding season, oestrus ( 1 or 2 days before ovulation, accompanied by behavioural oestrus), Days 1, 12, 14, 16 and 18 after ovulation (dioestrus) and from ovariectomized mares. Endometrium from pregnant mares was obtained by biopsy on Days $12,14,16$ and 18 after ovulation, and at hysterectomy on Days 29, 45, 65 and 100. Mares used on Days 39, 45, 65 and 100 of pregnancy were the same as those used for collecting conceptuses. Tissue from endometrial cups was utilized in other studies.

Biopsy samples were immediately placed into $5-\mathrm{ml}$ sterile tissue culture medium, and placed on ice for transport to the laboratory. A blood sample was obtained from each mare by jugular venepuncture and immediately placed on ice. After centrifugation $\left(2500 \mathrm{~g}\right.$ for $20 \mathrm{~min}$ at $\left.4^{\circ} \mathrm{C}\right)$ the plasma was stored frozen $\left(-20^{\circ} \mathrm{C}\right)$ until analysed. Surgical procedures were performed under general anaesthesia. Mares were tranquillized with acepromazine maleate $(4 \mathrm{mg} / 45 \mathrm{~kg}$ ). Anaesthesia was induced with thiamylal sodium (Biotal, $1 \mathrm{~g}$ ) and maintained with a mixture of halothane (Fluothane) and oxygen. The reproductive tract was exposed via a mid-ventral laparotomy, and the uterus and its contents were removed. Uteri containing conceptuses obtained at hysterectomy were clamped at the uterotubal junction and internal cervical os, placed in a sterile plastic bag, and transported on ice to the laboratory.

Tissue cultures. Eagle's minimum essential medium (MEM) was prepared as described by Basha et al. (1979), and used as described by Godkin et al. (1982). All media were deficient in the amino acid L-leucine. A conceptus (embryo and extraembryonic membranes, without capsule) was transferred to a sterile $10 \times 30 \mathrm{~mm}$ Petri dish with $2 \mathrm{ml}$ MEM (Days 12-15) or $15 \times 60 \mathrm{~mm}$ Petri dish with $5 \mathrm{ml}$ MEM (Days 16, 18, 22 and 28). Conceptuses at Days 39, 45, 65 and 100 were dissected from the uteri aseptically in a laminar flow hood. Yolk sac and chorioallantois were separated, and $500 \mathrm{mg}$ of each tissue, cut into approximately $3 \times 3 \mathrm{~mm}$ pieces, were incubated in duplicate in $15 \times 100 \mathrm{~mm}$ Petri dishes with $15 \mathrm{ml}$ MEM. Media were supplemented with $\mathrm{L}-\left[{ }^{3} \mathrm{H}\right]$ leucine $(50 \mu \mathrm{Ci}$ to whole conceptuses; $100 \mu \mathrm{Ci}$ to yolk sac and chorioallantois). On Days 14 and 15 a further 7 and 5 conceptuses, respectively, were incubated on each day, and media were subjected to polyacrylamide gel electrophoresis to examine the proteins synthesized from these additional conceptuses at this critical time period.

Endometrium was cut into pieces approximately $3 \times 3 \mathrm{~mm}$, and explants $(100 \mathrm{mg})$ were placed in sterile $10 \times 30 \mathrm{~mm}$ Petri dishes with $2 \mathrm{ml} \mathrm{MEM}$ and $50 \mu \mathrm{Ci} \mathrm{L}-\left[{ }^{3}\right.$ Hlleucine.d from Bioscientifica.com at 04/26/2023 09:34:41AM 
Endometrial biopsies obtained from 5 additional mares at Day 13 of dioestrus were used to assess the viability of the explants in culture by their ability to incorporate radioactive label in vitro. Explants were incubated for $20 \mathrm{~h}$ in $15 \times 60 \mathrm{~mm}$ Petri dishes with MEM to which $100 \mu \mathrm{Ci} \mathrm{L}-\left[{ }^{3} \mathrm{H}\right]$ leucine were added. At 4-h intervals, aliquants $(500 \mu \mathrm{l})$ were removed and replaced with equal amounts of leucine-deficient MEM. Incorporation of labelled leucine into macromolecules was monitored as counts retained after dialysis for $24 \mathrm{~h}\left(12000-14000 M_{\mathrm{r}}\right.$ retention) against $0.01 \mathrm{M}-$ Tris, $\mathrm{pH} 8 \cdot 2$, at $4^{\circ} \mathrm{C}$.

Polyacrylamide gel electrophoresis. The two-dimensional polyacrylamide gel electrophoresis (2-D PAGE) was performed by a modification of the method of O'Farrell (1975; O'Farrell et al., 1977) described by Roberts et al. (1984). The tissue culture medium was dialysed $\left(M_{\mathrm{r}} 12000-14000\right.$ retention) against $0 \cdot 01 \mathrm{M}$-Tris, $\mathrm{pH} 8 \cdot 2$, for $24 \mathrm{~h}$ with two changes of buffer. Labelled proteins in the medium ( 100000 c.p.m.) or plasma ( $300 \mu \mathrm{g}$; determined by the method of Lowry et al. 1951) were separated in the first dimension by isoelectric focussing (IEF) or by non-equilibrating $\mathrm{pH}$ gradient electrophoresis (NEPHGE), and in the second dimension on $10 \%$ polyacrylamide SDS slab gels. After electrophoresis, slab gels were impregnated with sodium salicylate (1 M; $30 \mathrm{~min}$ ) (Chamberlain, 1979) and dried; fluorograms were prepared (Laskey \& Mills, 1975) on Kodak XRP-1 X-ray film. Molecular weight $\left(M_{\mathrm{r}}\right)$ standards electrophoresed on the slab gels were $\beta$-galactosidase (116000), phosphorylase B $(97000)$, human transferrin $(77000)$, ovalbumin (45000), carbonic anhydrase (29000), soybean trypsin inhibitor $(20000)$ and cytochrome $\mathrm{C}(12500)$.

\section{Results}

\section{Conceptuses}

Representative fluorograms prepared from two Day-14 conceptuses and one Day-16 conceptus are shown in Fig. 1. The array of proteins represented in the upper panel was typical of the pattern produced by all conceptuses obtained before, and occasionally on, Day 14 after ovulation; this pattern was called the Early (E) pattern of protein synthesis. Two groups of proteins migrated with $M_{\mathrm{r}}$ between 30000 and 40000 (pI 4.5-5.5 and 6-7), and another cluster of polypeptides with $M_{\mathrm{r}} 22000$ (pI 6.5-7) (brackets). None of these polypeptides was readily identifiable after Day 14. One (group of) protein(s) $\left(M_{\mathrm{r}}>300000\right.$, whose size was estimated on the basis that it did not enter the $10 \%$ polyacrylamide gel) was evident on Days 12-18 (arrow).

The array of proteins shown in the middle panel, called the Late (L) pattern of protein synthesis, was produced only by some of the Day-14 conceptuses. This pattern appeared to be intermediate between the patterns produced by conceptuses before, and after, Day 14. The array of proteins shown in the lower panel was typical of proteins produced by whole conceptuses obtained on Days 15-18, 22 and 28. These proteins resembled those produced by isolated yolk sac at later stages of pregnancy (compare with Fig. 2). Included among these were proteins whose electrophoretic mobilities resembled those of alpha-fetoprotein and transferrin (Fig. 1, Day 16, parentheses) (Buhi et al., 1982; Godkin et al., 1985). Positive identification of these proteins is in progress. A group of acidic polypeptides $\left(M_{\mathrm{r}} 20000 ; \mathrm{pI} 5-6\right)$ was prominent from Day-14 Late and Day-16 conceptuses (brackets).

Isolated yolk sac membranes obtained through Day 100 of gestation primarily released acidic proteins in vitro. Representative fluorograms from Days 39, 45 and 65 are shown in Fig. 2 . The yolk sac membranes incorporated the radiolabel into proteins that migrated in a manner resembling alpha-fetoprotein and transferrin (parentheses; Buhi et al., 1982; Godkin et al., 1985). These proteins remain to be positively identified. Isolated chorioallantois synthesized and released acidic proteins, the majority of which had molecular weights of $<50000$ (Fig. 3).

No prominent proteins were observed in the NEPHGE fluorograms of any of the conceptusderived tissues.

\section{Endometrium}

The fluorograms of polypeptides released by endometrium could be assigned to one of three general groups, with endometrium from mares within each group producing similar patterns of labelled proteins. 
pl
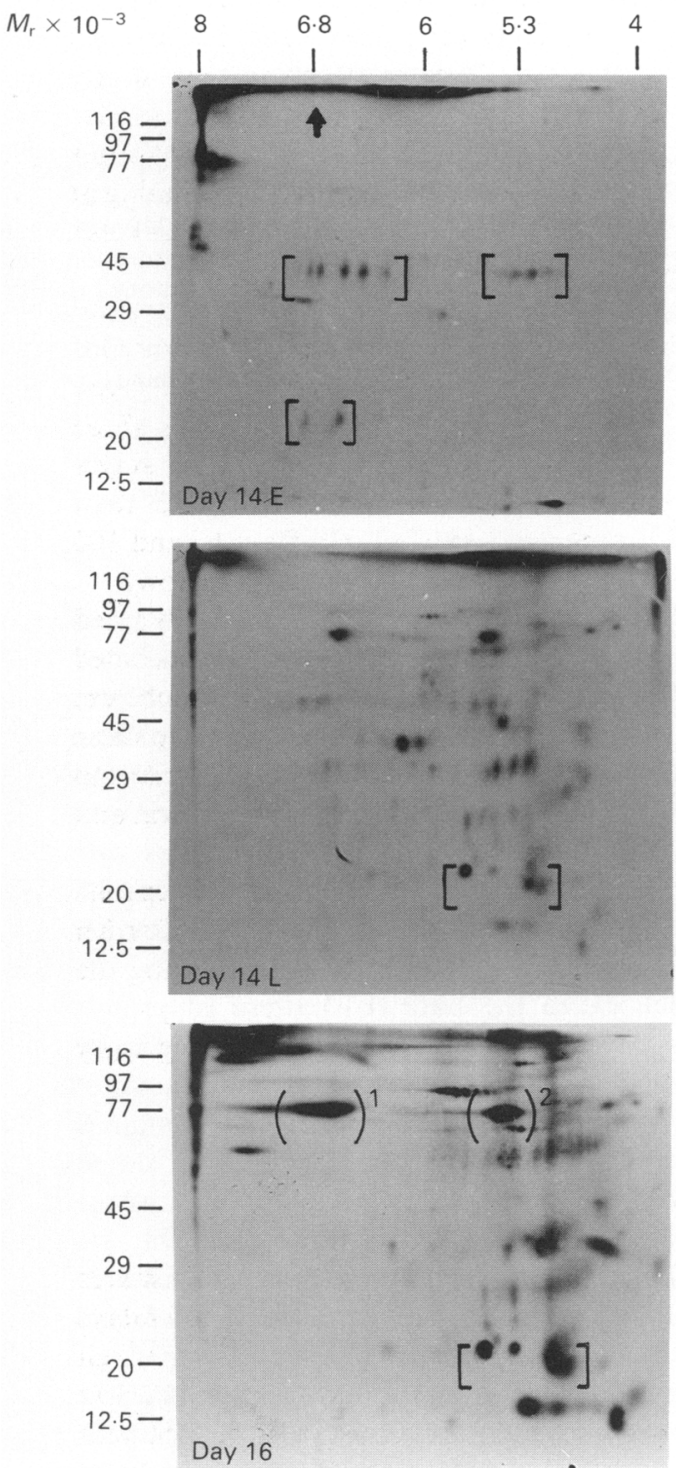

(Fig. 1)
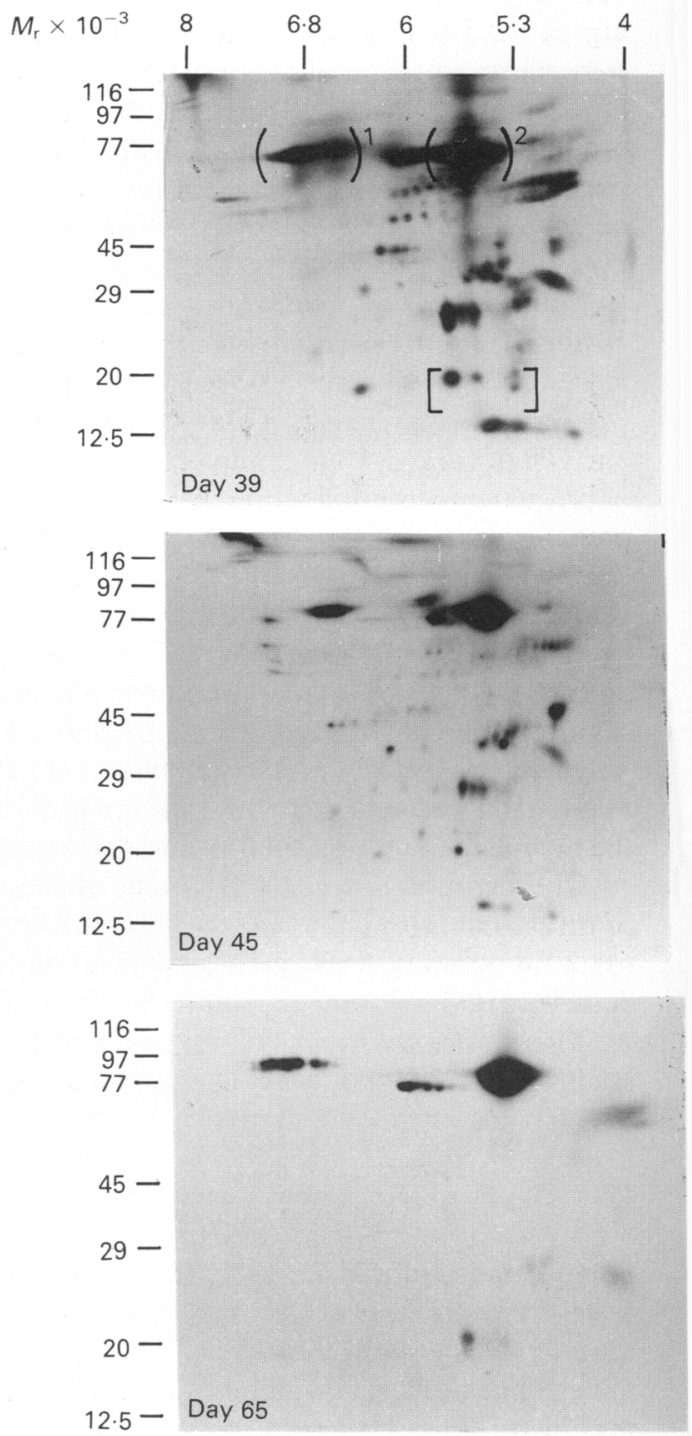

(Fig. 2)

Fig. 1. Representative fluorograms of 2-D PAGE gels showing major radiolabelled polypeptides synthesized and released into culture medium by 2 conceptuses collected at Day 14 and 1 at Day 16. Dominant in the Early pattern (D14E) were two groups of polypeptides with molecular weights between 30000 and 40000 (brackets), one group at 22000 (brackets) and a group of large proteins that did not enter the gel (arrow). The Late (D14L) pattern was produced by some Day- 14 conceptuses. Day 14 Late and Day 16 conceptuses produced a group of acidic polypeptides at approximately $20000 M_{\mathrm{r}}$ (brackets), as well as proteins resembling transferrin and alpha-fetoprotein in their electrophoretic mobilities (parentheses 1 and 2). Fluorograms were exposed for 4 weeks. 
The first group consisted of anoestrous, transitional, ovariectomized mares, and mares at oestrus, Day 1 or Day 18 after ovulation. Fluorograms from these mares are represented in Fig. 4, top panel. The two polypeptides with an approximate $M_{\mathrm{r}}$ of 12000 (pI values 5 and 6.5 ; arrows) were more pronounced in endometrium from mares on Day 1 or 18 after ovulation than at any other stages studied. Otherwise, endometrium from mares within this grouping produced similar proteins. Fluorograms of major radiolabelled products from mares on Days 12 and 14 after ovulation are shown in Fig. 4, middle and lower panels. Most prominent were proteins migrating at an $M_{\mathrm{r}}$ of $\sim 60000$ (pI 5.5-6.5) (brackets) and polypeptides of $M_{\mathrm{r}} \sim 22000$ (pI 5.5-6.5) (brackets). Proteins from mares at Day 16 after ovulation were identical to those at Day 14.

Fluorograms of proteins produced by endometrium from pregnant mares on Days 12, 14, and 18 are shown in Fig. 5. These fluorograms resembled, but were not identical to, those of dioestrous mares. Still prominent were the groups of proteins at an $M_{\mathrm{r}}$ of $\sim 60000$ and 22000 (brackets Day 14). Proteins from mares at Day 16 of pregnancy were identical to those at Day 18. On Days 45,65 and 100 of pregnancy, a group of $22000 M_{\mathrm{r}}$ polypeptides that resembled those in the earlier stages of pregnancy was present (brackets Day 65). Other proteins visible in fluorograms of Days 12-18 of pregnancy were not distinguishable in the later stages of pregnancy studied. On Days 65 and 100 there was a new protein $\left(M_{\mathrm{r}} \sim 80000\right)$ that had not been evident at any previous stage (arrow).

Four proteins consistently migrated into the NEPHGE fluorograms of endometrium obtained from mares during dioestrus and Days 12 through 65 of pregnancy. These proteins included uteroferrin $\left(M_{\mathrm{r}} 35000 ; \mathrm{pI} 9 \cdot 7\right)$ and a low molecular weight polypeptide $\left(M_{\mathrm{r}} 17000\right)$ which was slightly more basic than uteroferrin, identified as " $\mathrm{U}_{1}$ " by Zavy et al. (1982b). The other two basic polypeptides had molecular weights of $\sim 25000$ and $\sim 18000$, the former with a pI similar to uteroferrin, and the latter with a $\mathrm{pI}$ similar to " $\mathrm{U}_{1}$ ". By Day 100 of pregnancy, only uteroferrin and the polypeptide of $M_{\mathrm{r}} 22000$ were still identifiable (NEPHGE fluorograms not shown).

The incorporation of $\mathrm{L}-\left[{ }^{3} \mathrm{H}\right] \mathrm{leucine}$ into nondialysable macromolecules by endometrial explants of dioestrous mares proceeded slowly at first and increased to a more or less linear rate after $8 \mathrm{~h}$ (data not shown). This result indicated that protein synthesis continued to be active during the culture period.

There were no changes in plasma proteins at any stages of the oestrous cycle or pregnancy studied as depicted on Coomassie-blue stained polyacrylamide gels (Fig. 5; P).

\section{Discussion}

Polypeptides synthesized and released in vitro by conceptuses and endometria from pony mares have been characterized by $2-D$ PAGE and fluorography. The early pony conceptus ( $\leqslant 14$ days after ovulation) produced a distinct array of polypeptides, only one group of which, a very high molecular weight component, was evident after Day 14. Conceptuses from sheep, cows and pigs also released a large molecular weight glycoprotein $(>660000)$ during the preattachment elongation phase (Masters et al., 1982). Whether the product from the pony conceptus is similar to that of these other species is unknown. Moreover, varied amounts of radiolabel incorporated into such a large molecular weight component, which does not enter the $10 \%$ polyacrylamide gel, may account for apparent differences in intensities of the images evident on the fluorograms presented in

Fig. 2. Fluorograms of polypeptides synthesized and released in vitro by isolated yolk sac membranes at Days 39, 45 and 65 of pregnancy. Acidic polypeptides at $M_{\mathrm{r}} 20000$ on Day 39 (brackets) resembled those produced by whole cultured conceptuses on Days 14 (Late) and 16, and on Day 39 by chorioallantoic membranes (Fig. 3). Parentheses show proteins that are electrophoretically similar to transferrin (1) and alpha-fetoprotein (2). Fluorograms were exposed for 2 weeks. 


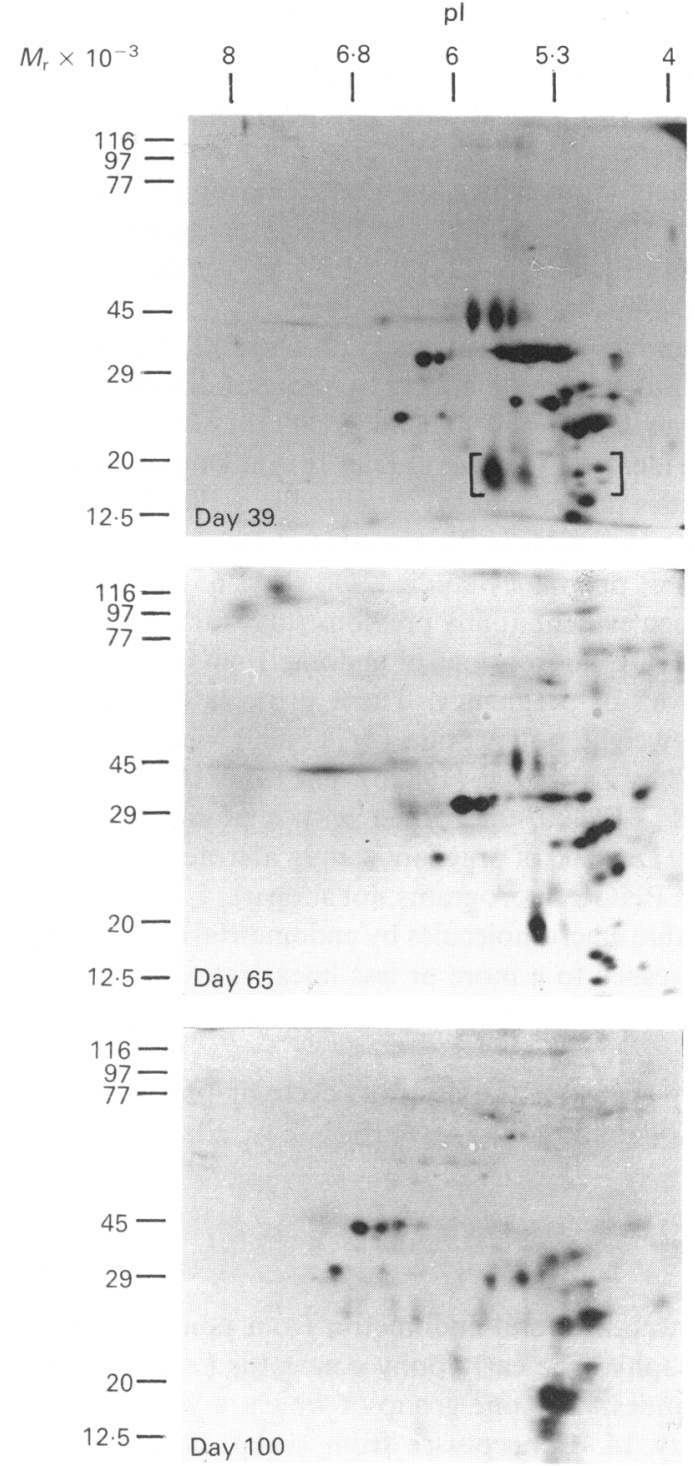

(Fig. 3)
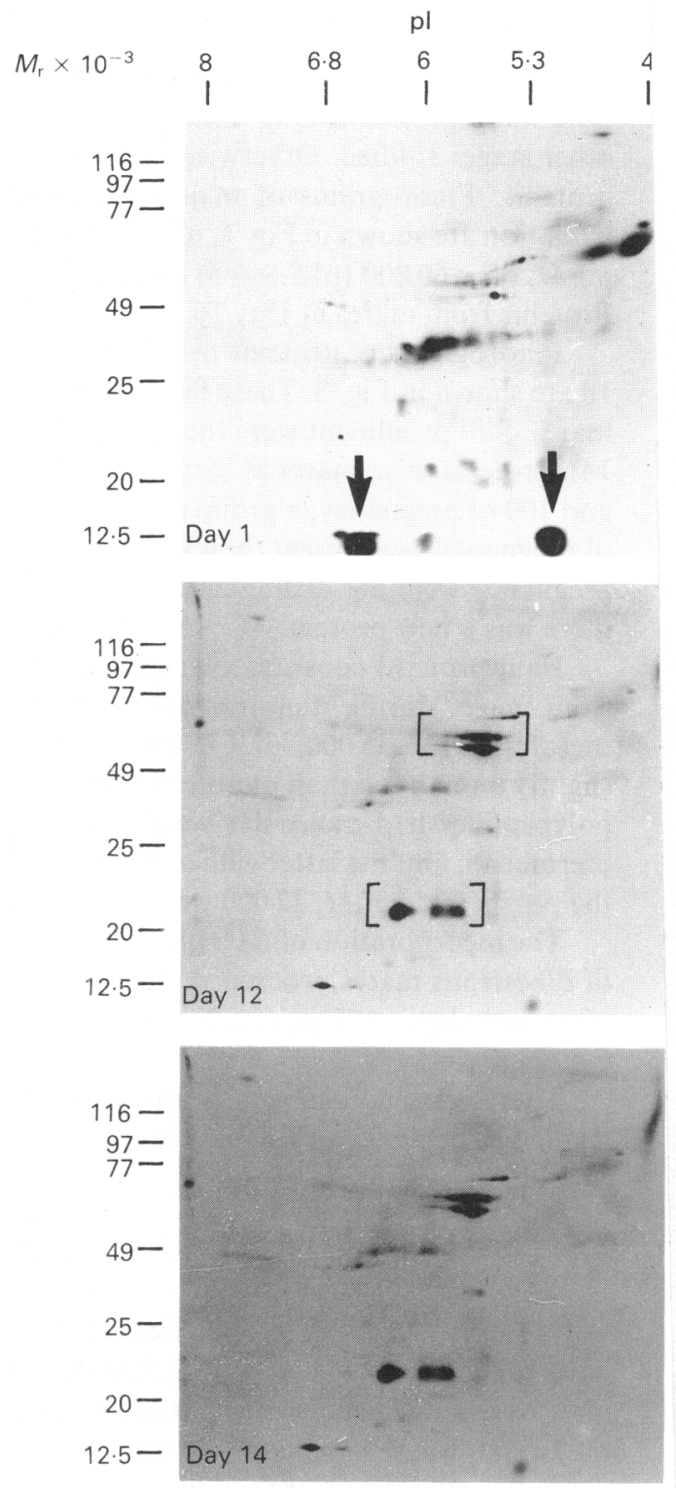

(Fig. 4)

Fig. 3. Fluorograms depicting polypeptides synthesized and released into MEM by isolated chorioallantoic membranes representing Days 39, 65 and 100 of pregnancy. Acidic polypeptides of $M_{\mathrm{r}} 20000$ are in brackets. Exposure time was 2 weeks.

Fig. 4. Representative fluorograms of 2-D PAGE gels showing major polypeptides from endometrial explant cultures on Days 1, 12 and 14 after ovulation. Two polypeptides were more prominent at D 1 than at other times (arrows). Brackets indicate major protein groups at $M_{\mathrm{r}} 22000$ and 60000 which were present during dioestrus and pregnancy. Exposure time was 2 weeks. 


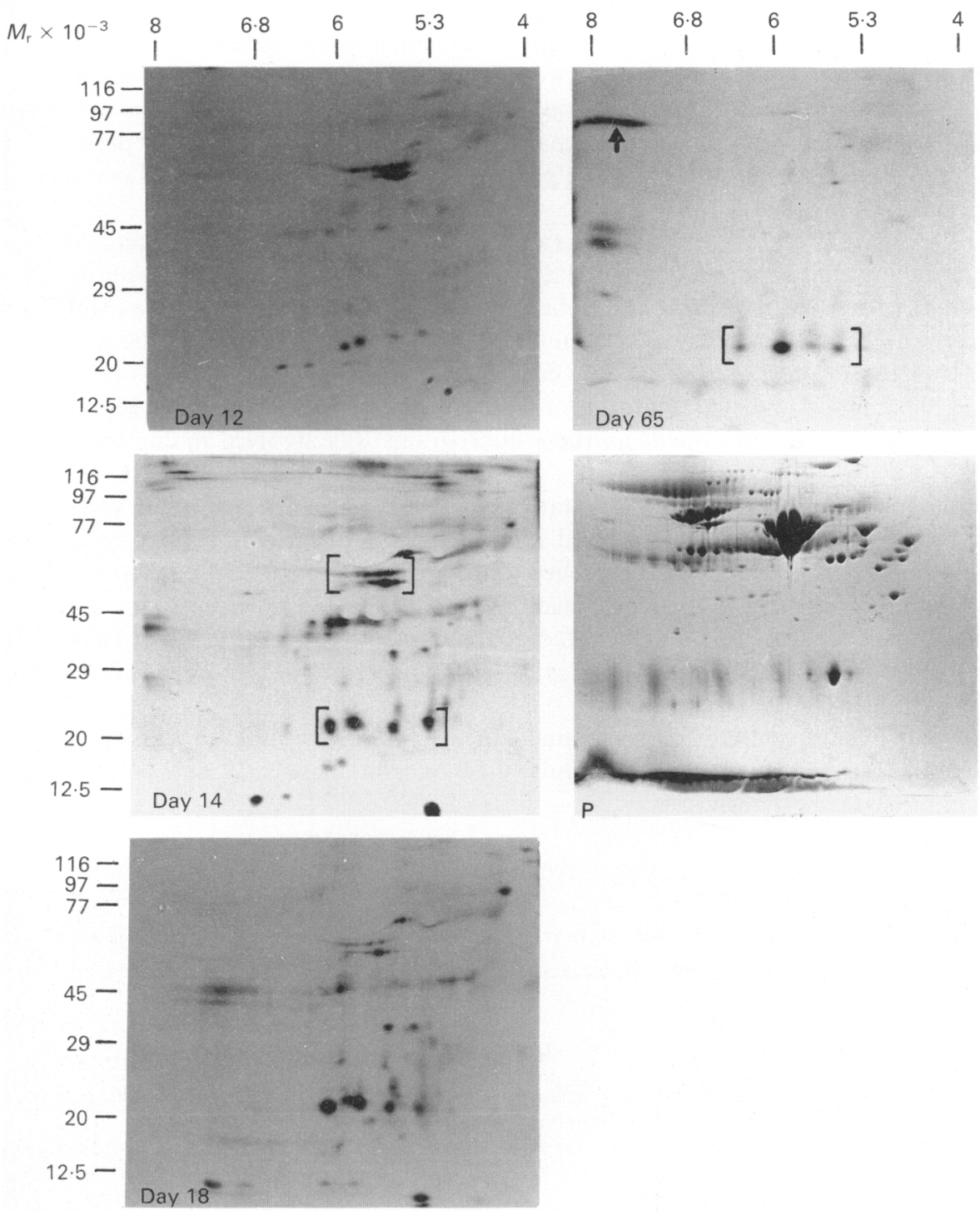

Fig. 5. Fluorograms of endometrial explants from pregnant mares, and Coomassie-blue stained 2-D PAGE gel of plasma proteins (P). Major proteins produced at $M_{\mathrm{r}} 22000$ and 60000 are bracketed. On Day 65 a new protein appeared (arrow). There were no changes in plasma proteins in any samples studied. Fluorograms were exposed for 2 weeks.

this study. Incomplete dialysis of low molecular weight products and unincorporated label may also account for apparent differences in intensities of the images.

Day 14 was clearly a transitional day for changes in the patterns of proteins produced by the pony conceptus, as determined by 2-D PAGE and fluorography. The mesoderm with its associated blood-forming islets is developing by Day 14 or 15 (Ginther, 1979), and this developmental transition may result in the changes in protein patterns observed in this study. Isolated chorioallantois produced a wide array of relatively low molecular weight $(<50000)$ acidic proteins, most of which appeared to be different from those of yolk sac origin. Their identities are unknown at this time. Cultured whole conceptuses (Day 14 Late-Day 28), and aisolated yolk isaciand chorioallantoic $09: 34: 41 \mathrm{Am}$ 
membranes (Day 39) produced a dominant group of acidic polypeptides with $M_{\mathrm{r}} 20000$. Whether these polypeptides are isoforms of the same proteins remains to be determined.

Proteins produced by endometrium between Days 12 and 18 of pregnancy were similar, but not identical, to those produced during dioestrus. The electrophoretic patterns of the 4-5 polypeptides $\left(M_{\mathrm{r}} 22000\right)$ varied between cyclic and pregnant mares. These differences may represent differences in post-translational modification of these polypeptides between dioestrus and pregnancy, and at different stages of pregnancy.

Uteroferrin was present during dioestrus and pregnancy. Uteroferrin is a purple, iron-containing acid phosphatase that has been characterized in uterine secretions and from endometrial explant cultures in the sow (Basha et al., 1979; Buhi et al., 1982), horse and pony mare (McDowell et al., 1982; Zavy et al., 1982b; McDowell, 1986). A protein of neutral pl, $M_{\mathrm{r}} \sim 80000$ was apparent on Days 65 and 100 of pregnancy. This time corresponded to maximum activity of the endometrial cups, and the humoral and cytotoxic attack on the cups by the endometrium (Allen, 1979). It is not known whether the protein evident on these fluorograms was involved in cup formation or cup activity.

Like the results in this study, few qualitative differences were observed in the arrays of proteins produced by endometrial explants obtained at various stages of early pregnancy in cattle (Bartol $e t$ al., 1985), pigs (Basha et al., 1980) or sheep (Moffatt et al., 1980), although ovine trophoblast protein-1 has been reported to induce changes in proteins secreted by sheep endometrium (Godkin et al., 1984; Vallet et al., 1987). Further studies are necessary to identify whether pony conceptus secretory proteins induce changes in the synthesis and secretion of endometrial proteins of the mare.

Conceptus signals resulting in luteal maintenance in ponies have not yet been identified, but one or more of the proteins identified in the culture medium from these early embryos may be involved in the antiluteolytic mechanism.

Supported by grants from The Morris Animal Foundation to D.C.S. and National Institutes of Health (HD 10436) to R.M.R.

The investigation reported in this paper (No. 89-4-163) is in connection with a project of the Kentucky Agricultural Experiment Station and is published with approval of the Director.

\section{References}

Allen, W.R. (1979) Maternal recognition of pregnancy and immunological implications of trophoblastendometrium interactions in equids. In Maternal Recognition of Pregnancy (Ciba Fdn Symp. No. 64), pp. 323-352. Excerpta Medica, Amsterdam.

Bartol, F.F., Roberts, R.M., Bazer, F.W. \& Thatcher, W.W. (1985) Characterization of proteins produced in vitro by bovine endometrial explants. Biol. Reprod. 33, 745-759.

Basha, S.M.M., Bazer, F.W. \& Roberts, R.M. (1979) The secretion of uterine specific purple phosphatase by cultured explants of porcine endometrium. Dependency upon the state of pregnancy of the donor animal. Biol. Reprod. 20, 431-441.

Basha, S.M.M., Bazer, F.W. \& Roberts, R.M. (1980) Effect of the conceptus and qualitative aspects of uterine secretion in pigs. J. Reprod. Fert. 60 , 41-48.

Bazer, F.W. \& First, N.L. (1983) Pregnancy and parturition. J. Anim. Sci., Suppl. 2, 425-460.

Beier, H.M. \& Mootz, U. (1979) Significance of maternal uterine proteins in the establishment of pregnancy. In Maternal Recognition of Pregnancy (Ciba Fdn
Symp. NS, No. 64), pp. 111-140. Excerpta Medica, Amsterdam.

Betteridge, K.J. \& Mitchell, D. (1974) Direct evidence of retention of unfertilized ova in the oviduct of the mare. J. Reprod. Fert. 39, 145-148.

Betteridge, K.J., Eaglesome, M.D. \& Flood, P.F. (1979) Embryo transport through the mare's oviduct depends upon cleavage and is independent of the ipsilateral corpus luteum. J. Reprod. Fert., Suppl. 27, 387-394.

Biggers, J.D. \& Borland, R.M. (1976) Physiological aspects of growth and development of the preimplantation mammalian embryo. Ann. Rev. Physiol. 38, 95-119.

Buhi, W.C., Ducsay, C.A., Bazer, F.W. \& Roberts, R.M. (1982) Iron transfer between the purple phosphatase uteroferrin and transferrin and its possible role in iron metabolism of the fetal pig. J. biol. Chem. 257, 1712-1723.

Chamberlain, J.P. (1979) Fluorographic detection of radioactivity in polyacrylamide gels with the watersoluble fluor, sodium salicylate. Analyt. Biochem. 98, Downl132ed 35.om Bioscientifica.com at 04/26/2023 09:34:41AM 
Ginther, O.J. (1979) Reproductive Biology of the Mare. Basic and Applied Aspects. McNaughton and Gunn, Inc., Ann Arbor.

Ginther, O.J. (1983) Mobility of the early equine conceptus. Theriogenology 19, 603-611.

Godkin, J.D., Bazer, F.W., Lewis, G.S., Geisert, R.D. \& Roberts, R.M. (1982) Synthesis and release of polypeptides by pig conceptuses during the period of blastocyst elongation and attachment. Biol. Reprod. 27, 977-987.

Godkin, J.D., Bazer, F.W. \& Roberts, R.M. (1984) Ovine trophoblast protein 1 , an early secreted blastocyst protein, binds specifically to uterine endometrium and affects protein synthesis. Endocrinology 114, $120-130$.

Godkin, J.D., Bazer, F.W. \& Roberts, R.M. (1985) Protein production by cultures established from Day14-16 sheep and pig conceptuses. J. Reprod. Fert. 74, 377-382.

Laskey, R.A. \& Mills, A.D. (1975) Quantitative film detection of ${ }^{3} \mathrm{H}$ and ${ }^{14} \mathrm{C}$ in polyacrylamide gels by fluorography. Eur. J. Biochem. 252, 6510-6515.

Liggins, G.C., Fairclough, R.J., Grieves, S.A., Kendall, J.Z. \& Knox, B.S. (1973) The mechanism of initiation of parturition in the ewe. Recent Prog. Horm. Res. 29, $111-159$.

Lowry, O.H., Rosebrough, N.C., Farr, A.L. \& Randall, R.J. (1951) Protein measurements with the Folin phenol reagent. J. biol. Chem. 193, 265-275.

Masters, R.A., Roberts, R.M., Lewis, G.S., Thatcher, W.W., Bazer, F.W. \& Godkin, J.D. (1982) High molecular weight glycoproteins released by expanding, pre-attachment sheep, pig and cow blastocysts in culture. J. Reprod. Fert. 66, 571-583.

McDowell, K.J. (1986) Establishment of pregnancy in mares: inter-relationships among uterine proteins, prostaglandin $F_{2 \alpha}$ and conceptus secretory proteins. Ph.D. Dissertation. University of Florida, Gainesville.

McDowell, K.J., Sharp, D.C., Fazleabas, A.T., Roberts, R.M. \& Bazer, F.W. (1982) Partial characterization of the equine uteroferrin-like protein. J. Reprod. Fert., Suppl. 32, 329-334.

McDowell, K.J., Sharp, D.C., Peck, L.S. \& Cheeves, L.L. (1985) Effect of restricted conceptus mobility on maternal recognition of pregnancy in mares. Equine vet. J., Suppl. 3, 23-24.

McDowell, K.J., Sharp, D.C., Grubaugh, W., Thatcher, W.W. \& Wilcox, C.J. (1988) Restricted conceptus mobility results in failure of pregnancy maintenance in mares. Biol. Reprod. 39, 340-348.

Moffatt, R.J., Bazer, F.W., Caton, D. \& Roberts, R.M. (1980) Secretory activity of endometrium from preg- nant and nonpregnant uterine horns of ewes. $J$. Anim. Sci. 51, (Suppl.) 307, abstr.

O'Farrell, P.H. (1975) High resolution, two-dimensional polyacrylamide gel electrophoresis of proteins. $J$. biol. Chem. 250, 4007-4021.

O'Farrell, P.Z., Goodman, H.M. \& O'Farrell, P.H. (1977) High resolution two-dimensional electrophoresis of basic as well as acidic proteins. Cell 12, 1133-1142.

Roberts, R.M., Baumbach, G.A., Buhi, W.C., Denny, J.B., Fitzgerald, L.A., Babelyn, S.F. \& Horst, M.N. (1984) Analysis of membrane polypeptides by twoimensional polyacrylamide gel electrophoresis. In Molecular and Chemical Characterization of Membrane Receptors, ch. 3, pp. 61-113. Eds J. C. Venter \& L. C. Harrison. Alan R. Liss, Inc, New York.

Short, R.V. (1969) When a conceptus fails to become a pregnancy. In Foetal Autonomy (Ciba Fdn Symp. No. 111), pp. 2-26. Eds. G. E. W. Wolstenholme \& M. O'Connor. Churchill, London.

Thatcher, W.W., Wilcox, C.J., Bazer, F.W., Collier, R.J., Eley, R.M., Stover, D.G. \& Bartol, F.F. (1979) Bovine conceptus effects prepartum and potential carryover effects postpartum. In Animal Reproduction, pp. 259-275. Ed. H. W. Hawk. Allenheld Osumn, Montclair.

Vallet, J.L., Bazer, F.W. \& Roberts, R.M. (1987) The effect of ovine trophoblast protein-one on endometrial protein secretion and cyclic nucleotides. Biol. Reprod. 37, 1307-1316.

Zavy, M.T., Clark, W.R., Sharp, D.C., Roberts, R.M. \& Bazer, F.W. (1982a) Comparison of glucose, fructose, ascorbic acid and phosphohexose isomerase activity in uterine flushings from non-pregnant and pregnant gilts and pony mares. Biol. Reprod. 27, $1147-1158$.

Zavy, M.T., Sharp, D.C., Bazer, F.W., Fazleabas, A., Sessions, F. \& Roberts, R.M. (1982b) Identification of stage specific and hormonally induced polypeptides in the uterine secretions of the mare during the oestrous cycle and pregnancy. J. Reprod. Fert. 64, 199-207.

Zavy, M.T., Vernon, M.W., Sharp, D.C. \& Bazer, F.W. (1984) Endocrine aspects of early pregnancy in pony mares: a comparison of uterine luminal and peripheral plasma levels of steroids during the estrous cycle and early pregnancy. Endocrinology 115 , 214-219.

Received 1 August 1989 